than ninety miles. The task of unravelling the geological structure of these southern regions will be much facilitated by the remarkable persistence of the Sutherland Silurian zones, some of which, with their characteristic features and fossils, are as well marked above Loch Carron as they are at Loch Eriboll.

In south-western Ross-shire the platform on which the Silurian rocks rest is a thick mass of Cambrian red sandstone. In the great upthrow, it is this sandstone platform which has there been pushed over the limestones and quartzites. On the west side of Loch Keeshorn, the red sandstones, in their normal unaltered form, rise up into the colossal pyramids of Applecross; but on the east side, where, at a distance of little more than a mile, they overlie the limestones, they bear so indurated an aspect that they have naturally been classed with the quartzose members of the Silurian series. Traced eastwards they present increasing evidence of intense shearing ; fluxion-structure makes its appearance in them, with a development of mica along the divisional planes, until they pass into frilled micaceous schist, in which, however, the original clastic grains are still recognisable. They finally shade upwards into green schists and fine gneiss which merge into coarse gneiss with pegmatite. The short space within which ordinary red feldspathic sandstone and arkose acquire the characters of true schists is a point of some importance in regard to the change from the unaltered Silurian strata of the Southern Uplands into the metamorphic condition of the Highland phyllites, grits, \&c.

Obviously the question of chief importance in connection with the structure now ascertained to characterise the North-West Highlands relates to metamorphism. That there is no longer any evidence of a regular conformable passage from fossiliferous Silurian quartzites, shales, and limestones upwards into crystalline schists, which were supposed to be metamorphosed Silurian sediments, must be frankly admitted. But in exchange for this abandoned belief, we are presented with startling new evidence of regional metamorphism on a colossal scale, and are admitted some way into the secret of the processes whereby it has becn produced.

From the remarkably constant relation between the dip of the Silurian strata and the inclination of their reversed faults, no matter into what various positions the two structures may have been thrown, it is tolerably clear that these dislocations took place before the strata had been seriously disturbed. The persistent parallelism of the faults and of the prevailing north-easterly strike of the rocks indicates that the faulting and tilting were parts of one continuous process. The same dominant northeasterly strike extends across the whole Highlands, and also over the Silurian tracts of Southern Scotland and the North of England. There is reason to regard it in all these regions as probably due to one great series of terrestrial movements. These must have occurred some time between an early part of the Silurian period and that portion of the Old Red Sandstone period represented by the brcccias and conglomerates of the Highlands. In the Central and Eastern Highlands the slates, phyllites, grits, quartzites, and limestones which, along the southern border, are scarcely more altered than their probable equivalents among the Silurian rocks of the Southern Uplands, have been greatly plicated, and have assumed a more or less crystalline structure. But when these changes were brought about, there lay to the northwest a solid ridge of Archæan gneiss and Cambrian sandstone which offered strong resistance to the plication. The thrust from the eastward against this ridge must have been of the most gigantic kind, for huge slices, hundreds of feet in thickness, were shorn off from the quartzites, limestones, red sandstones, and gneiss, and were pushed for miles to the westward. During this process, all the rocks driven forward by it had their original structure more or less completely effaced. New planes, generally parallel with the surfaces of movement, were developed in them, and along these new planes a rearrangement and recrystallisation of mineral constituents took place, resulting in the production of crystal. line schists. This metamorphism certainly occurred after early Silurian times, for Cambrian and Lower Silurian strata, as well as Archæan rocks, have been involved in it.

It is obvious that into the problems of Highland geology, always admittedly obscure, a fresh element of difficulty is introduced. At the same time the aid furnished by a minute study of the Sutherland sections is so great that we may hope to attack these problems with more success than has hitherto seemed probable. The work, too, is not of a kind to be attempted in a few hasty scampers over the ground. It will require patient detailed mapping. But when the great base-lines have once been accurately traced, the difficulties will doubtless begin to diminish, and, like the pieces of a puzzle, the various segments of the Highlands will then be found to range themselves in their proper places.

ARCH. GEIKIE

\section{Report on the Gcology of the North-West of Sutherland}

IN the north-west of Sutherland the most ancient rocks belong to the Archæan series, and present a great uniformity in lithological characters. They consist mainly of coarse hornblendic gneiss, with distinct zones of gray and pink granitoid gneiss, in which the mica is more abundant than the hornblende. Lenticular veins and bosses of hornblende-rock and hornblende-schist, some at least of which are evidently intrusive, occur in the gneiss, while the presence of small kernels of cleavable hornblende and actinolite forms another characteristic feature of the series. Veins of pink or white pegmatite abound, sometimes parallel with the foliation of the gneiss and sometimes traversing it in all directions. These, however, are distinct from dykes of pink granite, which also intersect the gneiss and coarse pegmatites, and are themselves crossed by later pegmatite-veins. Here and there, indeed, the branches of a pegmatite-vein can be seen to return upon themselves and traverse the main trunk from which they start. Where the Archæan rocks have been recently stripped of their former cover of Silurian quartzite, bands of green epidotic gneiss appear among them, and a soft green mineral with a greasy lustre (agalmatolite?) is there characteristic of the superficial parts of the pegmatite-veins.

The highly crystalline Archaan rocks are overlain unconformably by a succession of conglomerates, grits, and sandstones, regarded by Murchison as the equivalents of the Cambrian system of Wales. In the course of the work of the Geological Survey in the present region they have been divided into certain zones, which, though they need not be stated here, as they have no bearing on the main question to which this paper is devoted, may prove to be of considerable importance in unravelling the geological structure of the districts further south.

Between the Cambrian sandstones and the overlying quartzites at the base of the Silurian serics there is a complete discordance. To the west of the Kyle of Durness, for example, the Cambrian sandstones dip to the north-west, while the overlying quartzites dip to the south of east. Moreover, as the observer passes eastwards to the shores of the Kyle, the Cambrian sandstones are bed after bed transgressed by the quartzites, which eventually rest directly on the Archran gneiss. The Silurian strata in the Durness area (A in Section) consist of a calcareous series at the top; a middle series, composed partly of calcareous and partly of arenaceous strata; and an arenaceous series at the base. The various sub divisions of the strata are given in descending order in the subjoined tabular statement. 


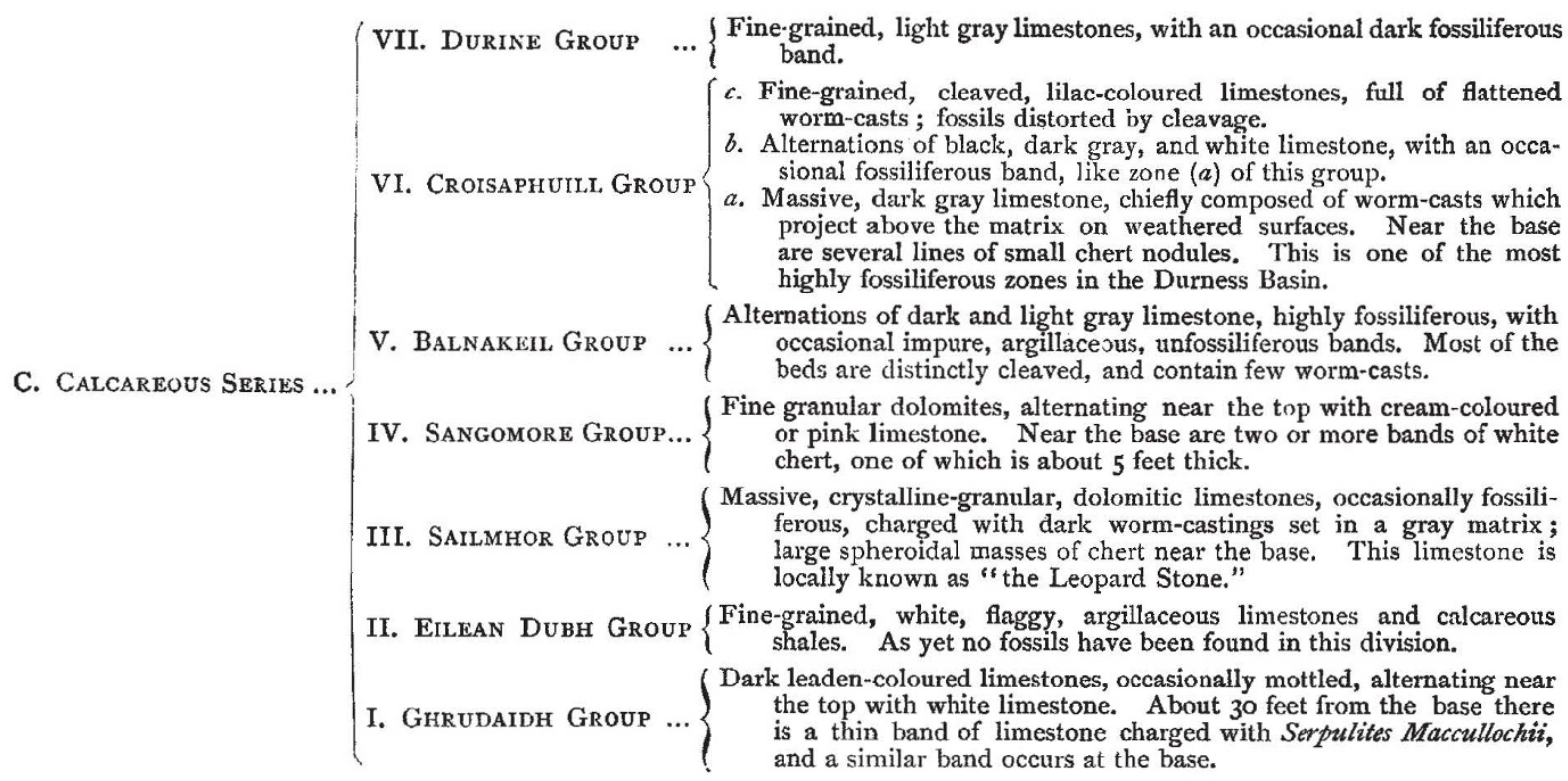

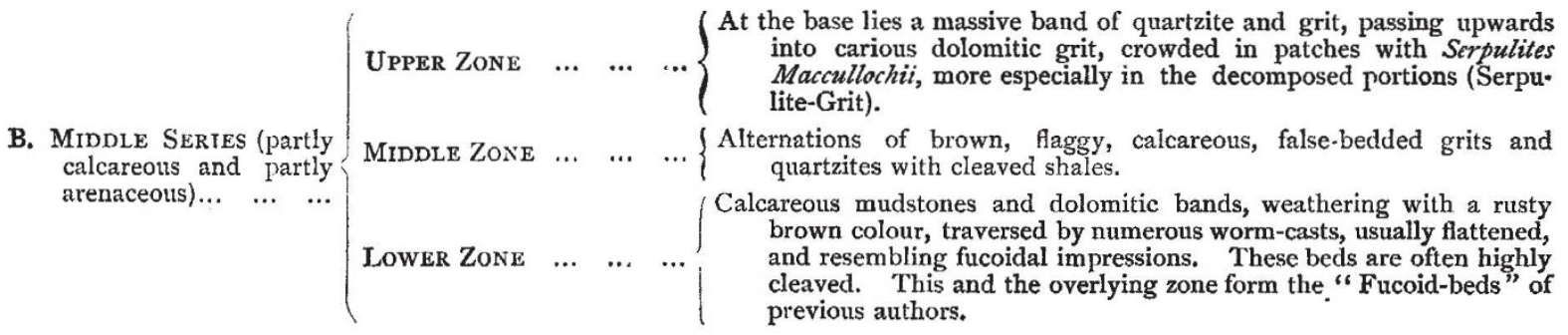

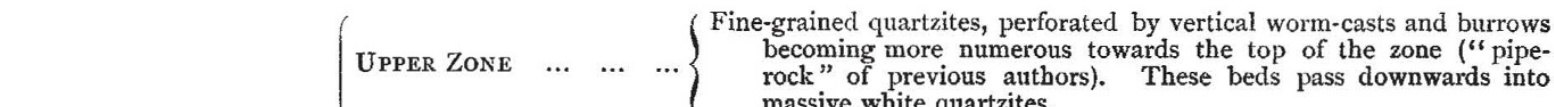
( massive white quartzites.

A. Arenaceous Series... $\left\{\begin{array}{c}\text { False-bedded flaggy grits and quartzites, composed of grains of quartz } \\ \text { and feldspar. At the base there is a thin brecciated conglomerate, }\end{array}\right.$ LOWER ZONE $\quad \ldots \quad \ldots \quad \ldots \quad$ and feldspar. At the base there is a thin brecciated conglomerate, pebbles of the underlying rocks, chiefly of quartz and orthoclase, the largest measuring about $\mathrm{I}$ inch across.

The Silurian strata in the Durness area are arranged in the form of a basin, truncated on the east side by a fault that brings them against the Archæan gneiss, and thus disconnects them from the Eriboll area, with which they were certainly at one time united. Of the identity of these strata in the two areas there cannot be the smallest doubt. We have recognised them zone by zone, completing the proofs of this identity by detecting in the south and central parts of the Durness Basin the representatives of the middle series, viz. the "Fucoid-beds" and "Serpulite-grit," which had not previously been noted in that area. Though subject to local variations in thickness, these zones are singularly persistent, and, from their marked lithological characters and fossil contents, constitute admirable horizons in unravelling the complicated geological structure of the region. A rich assemblage of fossils has been obtained by the Survey from the various fossiliferous bands indicated in the foregoing table, comprising Trilobites, Annelids, Cephalopods (Nautilus, Litnites, Orthoceras, Piloceras, \&c.), Heteropods, Gasteropods, Lamellibranchs, Brachiopods, Corals, Sponges, and Foraminifera. As yet this collection has not been examined in detail, but from observations in the field it is probable that some of the limestone zones will be found to be characterised by particular fossils.

A striking feature of the Durness Basin is the amount of displacement of the strata by faults; indeed, this feature is so characteristic of the highest limestone zones that it is difficult satisfactorily to compute their thickness. But from the base of the quartzite to the top of the calcareous series the total thickness of Silurian strata cannot be less than 2000 feet. In Sangomore Bay, near the village of Durine, the highest limestone zone is overlain by shattery quartzite, striped fissile schist, frilled schists, and gneiss. Though unquestionably resting upon the limestone and sharing in the normal faulting of the district, these crystalline strata do not prove a conformable upward succession, as has been naturally enough supposed. The key to the reading of this and of the corresponding section at Farrid Head is to be sought in the Eriboll tract.

The Silurian rocks of the Durness Basin are separated from those of Loch Eriboll ( $\mathrm{B}$ in the Section) by a prominent ridge of Archæan gneiss, the eastern slope of which is covered by a cake of quartzite. Along the crest of the chain the basal breccia is exposed, overlain by the lower zone of false-bedded grits (No. 3) and the upper zone of "pipe-rock" (No. 4 in Section). As the eastern declivity of the ridge is greater than the dip of the quartzites, the observer, on descending the slope, crosses the basset edges and dip-slopes of the latter strata, and eventu- 
ally finds himself again on the old platform of Archæan gneiss exposed by denudation (see Section). Both the zones of quartzite are then once more met with in their normal order, the highest beds exposed on the western shore of Loch Eriboll belonging to the horizon of the "pipe-rock." On the eastern shore, at Ant Sron, on the crest of a low anticlinal arch of the "pipe-rock," there is an excellent section of the middle series between the quartzites and the limestones. The two subdivisions of the "Fucoid-beds" (No. 5) and the "Serpulite-grit" (No.6 in Section), which are typically developed at that locality, pass underneath the Serpulite-limestone at the base of Group I., exactly as they do at Durness. The dark leadengray limestones of the lowest group (I.) are then rapidly succeeded by flaggy limestones (Ant Sron, Chorrie Island, Heilim) and dolomitic limestones which, probably the equivalents of the Eilean Dubh Group in Durness, are the highest members of the series here represented (No. 7 in Section). A careful search among the Eriboll limestones has failed to bring to light any organic remains save Serpulites and certain minute spherical bodies which may prove to be Foraminifera. A similar dearth of fossils characterises the two lowest zones in Durness, so that this feature is common to both areas. The non-occurrence of the higher fossiliferous limestones in Eriboll may be accounted for by the remarkable geological structure of that region which is now to be described.
As the observer passes eastwards along the magnificent quartzite sections on Crag Dionard and Conamheall, south of Loch Eriboll, he cannot fail to note the numerous flexures of the strata, and especially the peculiar type of their sharp anticlinal folds. As a rule, the eastern limb of each of these folds dips at a gentle angle to the southeast, while the west limb is highly inclined, vertical, even inverted, or sometimes broken by a reversed fault the effect of which is to bring lower over higher beds. These reversed faults ( $t t t$ in Section) become more numerous eastwards. They are admirably displayed both in ground-plan and dipsection on the shore north of Heilim, where they repeat the various zones ranging from the "pipe-rock" to the Eilan Dubh limestone (Group II.). The strike of the reversed faults ranges on the whole with that of the strata traversed, and their hade is inclined at a higher angle than the dip of the latter, the difference generally amounting to about $10^{\circ}$. Inland from the coast-section, north of Heilim, to the base of Ben Arnaboll, the zones just mentioned are constantly repeated by a complicated system of reversed faults and folds, the general inclination of the strata being towards the south-east. As that hill is approached, the displacement produced by these faults increases in amount; hence the observer meets with beds occupying a lower geological horizon the further east he travels. At length this intricate system of faults and folds culminates in a great dislocation which, for convenience
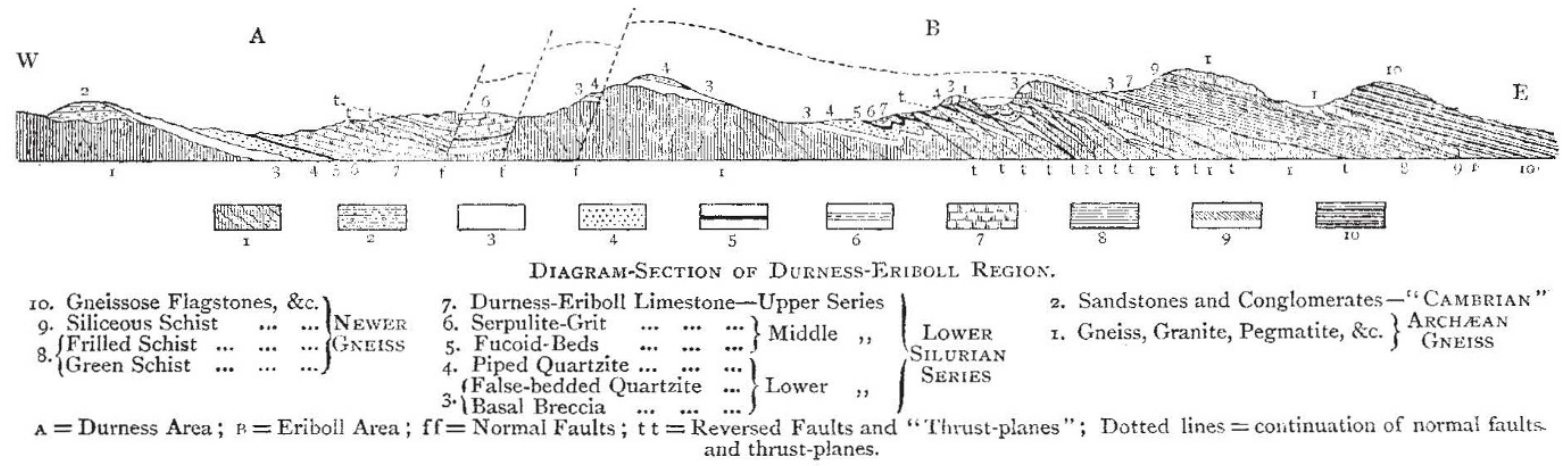

of description, and to distinguish it from the ordinary reversed faults, may be termed a Thrust-plane. By means of it a great mass of coarsely crystalline gneiss with pegmatite-veins, in places upwards of 400 feet thick, is placed above the Silurian rocks (see Section). A careful examination of the mass which caps Ben Arnaboll clearly proves that it rests transgressively on all the zones of the Silurian rocks, from the lower zone of the quartzites (false-bedded grits) up to the limestone which overlies the Serpulite-grit. Owing partly to its low hade and partly to subsequent folding, the outcrop of this thrust-plane resembles that of an ordinary overlying formation cut into a sinuous line by denudation. It is admirably seen in dip-section on the east and north slopes of Ben Arnaboll, whence it can be followed round the west face of the hill, descending into the valley on the west, then bending back on itself, winding round the north slope of Druim Tungi, and entering Loch Eriboll in Heilim Bay. It reappears at the base of Crag-na-Faolinn, and has been traced still farther to the south, while northwards it can be followed to the Whitten Head, at the mouth of Loch Eriboll.

That the gneiss thus brought up on Ben Arnaboll and elsewhere is in reality the Archæan gneiss is evident, for two reasons. First, its lithological characters agree with those of the typical Archæan area to the west, save in certain cases where the original features have been effaced by the crushing to be afterwards described. Near the thrust-plane, this effacement is complete, but in the heart of the mass the normal characters of the Archæan rocks, including in some instances their characteristie north-west strike, are retained. The rocks consist of coarsely crystalline hornblendic gneiss and pink granitoid gneiss, with lenticular veins of hornblendc-rock and kernels of cleavable hornblende, while massive veins of pink pegmatite are well developed. The soft greenish mineral (agalmatolite?) already mentioned as characteristic of the gneiss, where now or lately covered with quartzite, occurs here in the pegmatites, and veins of epidosite are abundant. Second, at various localities the brecciated conglomerate and false-bedded quartzite at the base of the Silurian strata are found resting on these crystalline rocks. Further, the unconformable junction can on one line be traced continuously for more than a mile. There can be no doubt, therefore, that this mass is really a fragment of the old platform of Archæan rocks on which the Silurian strata were deposited.

The occurrence of this Archæan gneiss in its present position above much younger rocks is doubtless to be ascribed to the same cause which elsewhere has resulted in foldings of the strata. In the present instance we see an attempt, as it were, to establish an anticlinal fold of the type already described as occurring to the west, with a steep westward and gentle eastward slope. The west limb however has here given way along a great dislocation or reversed fault, while the eastern limb has been driven forwards until the Archæan rocks have been carried over the truncated edges of the Silurian strata. The vertical beds of the basal quartzites are still 
to be seen on the west limb of the anticline on Ben Arnaboll, Crag-na-Faolinn, and on Whitten Head (see Section). The quartzites on Druim Tungi, and indeed all the Silurian strata on the east side of Loch Eriboll, between Heilim and Crag-na-Faolinn, form part of a syncline which has been pushed westwards in front of the anticline along this thrust-plane. This structure explains the origin of the inversion of the Silurian rocks along the junction line east of Camas-an-Duin, and the occurrence of the lower limestone groups in a shallow trough at Eriboll. Of special interest is the occurrence of a small outlier of Archæan gneiss on the crest of a hill (Sitheanna-Cuag) north-west of Ben Arnaboll. This mass rests on the Fucoid-shales, Serpulite-grit, and limestone. Though now isolated by denudation, it was obviously originally continuous with the mass on Ben Arnaboll, and it thus furnishes striking proof of the westward extension of displaced gneiss, and of the thrust-plane on which it travelled.

The effects of this great movement on the Silurian strata which have been over-ridden by the gneiss are somewhat remarkable. The pipes or vertical worm-tubes in the quartzites have been flattened, drawn out, and bent over in a direction perpendicular to the strike of the thrust-plane. The false-bedded grits and quartzites present a streaky appearance resembling fluxion-structure, due to the elongation of the fragments of orthoclasefeldspar and the quartz grains. The fine-grained rocks, especially the compact quartzites and the Fucoid-beds, are highly cleaved, the strike of the cleavage-planes being parallel with that of the thrust-plane, and this parallelism being maintained quite irrespective of any variation in the direction of dip of the strata next the gneiss. On the surface of the cleavage-planes also there is a series of parallel lines like slickensides which will be described presently; and lastly, there is a slight development of sericitic mica along many of the cleaved surfaces. No less important is the alteration produced on the overlying Archiean gneiss. In the heart of the mass, as already stated, there is little apparent change, but near the thrustplane the beds are drawn in towards it till their strike roughly coincides with that of the thrust-plane. The inclosed hornblende merges into a green chloritoid product, the hornblendic gneiss has been converted into a fine green schistose rock, while the quartz and feldspar of the pegmatites have been drawn out into streaky or wavy lines, so as to assume somewhat the appearance of rhyolites. Finally a new set of divisional planes has been superinduced on the mass, the strike of which is parallel with that of the plane of thrust.

Again, there is clear evidence to show that the thrustplane just described was followed by minor movements of a similar nature in the gneiss itself, whereby different portions of the mass were made to slip over each other. ()ccasionally a thin lenticular mass of the bottom-quartzite has been caught in these planes of disruption.

But all these evidences of displacement are merely the precursors of a still more powerful thrust-plane, which has been traced continuously from the shore east of Whitten Head to the crest of Crag-na.Faolinn, and at intervals for many miles to the southward into the Assynt country. The strike of the strata overlying this plane is, on the whole, north-north-east and south-south-west, with a general cast-south-easterly dip, usually at comparatively low angles. Though roughly parallel with it, this greater thrust-plane here and there overrides the lower or more westerly one, for the rocks on its upper side may be seen to pass across all the zones of the Silurian series up to the limestones. A recognisable and tolerably persistent order of succession has been observed in the rocks on the upper side of this thrust-plane. At the base, and resting on different platforms, there usually lies a belt of striped fissile schist, followed by grcen schist with alternations of gneiss, which, though it has lost nearly all trace of its original foliation, is probably a portion of the Archæan gneiss. A number of lenticular masses of Silurian quartzite occur on this horizon between the Whitten Head coast and Crag-na-Faolinn. In some cases, the basal breccia and portions of the overlying false-bedded grits are clearly seen resting on the Archæan rock, the planes of foliation of the gneiss being roughly parallel with the bedding of the quartzites. On closer examination, however, it is observable that successive folia of the gneiss impinge against the basal breccia. In other cases, wedges of the false-bedded grits, without the basal breccia, are caught between two thrust-planes. Perhaps the most remarkable example of these isolated masses of Silurian rocks, is the limestone intercalated among the green schists, on the hill-slope above Eriboll House. This mass appears to belong to one of the higher limestones of the Durness Basin which have not elsewhere been noticed in the Eriboll area. It lies not far above the great thrust-plane, and though its relations to the schists are not as well shown as could be desired, its presence here is evidently due to the same series of movements that brought in the intercalations of quartzite. Passing eastwards we find, next in order, a belt of frilled green schists (No. 8 in Section) with a well-marked calcareous zone near the top, which has been traced from the shore east of Whitten Head for a distance of ten miles in a south-west direction, and which extends still further to the south. To these succeed a thin band of compact siliceous schists (No. 9 in Section) overlain by hornblendic and micaceous gneiss, which is succeeded by a great development of gneissoid flagstones (No. IO) with occasional bands of hornblendic and micaceous garnetiferous schists.

This order of succession in the rocks above the upper thrust-plane is also recognisable far to the west in Sangomore Bay and on Farrid Head in the Durness area. It is evident that there has been an extraordinary amount of movement of these rocks along the upper thrust-plane, since they override all the other rocks pushed forward by the lower thrust-planes in the Eriboll area, and rest directly on the limestones of the Durness Basin. The thin band of shattery quartzite between the striped fissile schist and the limestone in Sangomore Bay is a fragment of the falsc-bedded quartzite zone which has been pushed forward along the surface of the thrust-plane,-a characteristic feature of the thrust-planes in Eriboll.

The microscopic characters of the rocks from the different zones above the upper thrust-plane have yet to be studied. Much fresh light may thence be expected on the modus operandi of the processes involved in the extraordinary lithological changes which the rocks have undergone. Meanwhile a careful cxamination of the various masses in the field points very clearly to the nature of these processes. The striped green fissile schist which occurs along the thrust-plane presents an exceedingly compact texture with a remarkable streaked structure which at once recalls the fluxion-lines of an eruptive rock. Still more conspicuously is this structure displayed by the masses of pegmatite in the gneiss; they lose their ordinary character and assume more that of rhyolite. The intercalations of quartzite are marked likewise by the same streaked appearance, their component particles of quartz and feldspar being all elongated in one common direction. The gneiss associated with the schists above the thrust-plane, though its original foliation can still in places be detected, has had a new set of schistose planes superinduced in it which are on the whole parallel with the thrust-plane. Bands of hornblendic gneiss merge into hornblende-schist and chloriteschist, and these again into finely-frilled schists. All these new structures, which are quite independent of the original bedding or foliation of the rocks, were obviously connected with the production of the great thrust-plane, with which they lie more or less parallel. They point to 
enormous mechanical movements under which, as the rocks sheared, the individual particles were forced over each other in one common direction, viz. from eastsouth-east to west-north-west. Further evidence of this mechanical movement is supplied by certain abundant fine parallel lines, like those of slickensides, which occur almost everywhere on the foliation-surfaces or other parallel divisional planes. They are especially well developed among the striped fissile schists and the gneissose flagstones. These lines run in the same general direction already mentioned (E.S.E. to W.N.W.). In many cases it may be observed that the component particles of the rocks are oriented in this same direction, while original quartz-veins are drawn out into parallel rods. Another important feature connected with these rocks is the development of minerals along the new planes of schistosity. In particular, the abundance of sericite mica is noteworthy, the longer axes of the crystals of which lic in a direction parallel with the slickenside-lines. Other micas, hornblende, actinolite, and garnets have also made their appearance along the same planes. This recrystallisation becomes more pronounced the further east one advances from the outcrop, or passes upwards from the great thrust-planc.

This accumulated evidence points to the conclusion that in the north-west of Sutherland the rocks have been powerfully affected by one grand series of terrestrial movements whereby new structures have been superinduced upon them. Among these changes the original characters of the rocks have been more or less completely effaced, and new crystalline structures have been produced. Although a normal upward succession from the Silurian strata into an overlying series of schists cannot be maintained in the north of Sutherland, it is nevertheless certain that the displacements and metamorphism here described are later than Lower Silurian time. It is also evident that these great changes had been completed before the timc of the Lower Old Red Sandstone, the conglomerates and breccias of which rest upon and are made up of fragments of the crystalline schists.

One final feature of the Durness and Eriboll area remains to be noticed. The geological structure of this region has been further complicated by the subsequent folding of the strata, and by a double system of normal faults ( $f f$ in Section) which affect the strata and thrust-planes alike. One set of normal faults trends north-north-east and southsouth-west, while another, which appears to be newer, trends more or less at right angles to these. By these two systems of later dislocations, the thrust-planes with their low hade have been intersected and shifted precisely as if they had been ordinary boundary-planes between two geological formations. Much of the difficulty, indeed, which has been from the first experienced in unravelling the complicated structure of this region may be traced to the effect of the intricate network of reversed and normal faulting. The very preservation of the Durness Basin is due to two normal step-faults, one of which lets down the quartzites more than $\mathrm{I} 200$ feet, while the other brings the whole Silurian Basin down to the sea-level.

B. N. PLACH JOHN HORNE

\section{THE GENESTS OF AN IDEA, OR STORY OF A DISCOVERY RELATING TO EQUATTONS IN MULTIPLE QUANTITY}

I VENTURE, even at the risk of appearing egoistical, to call the attention of a wider circle of English mathematical readers than are likely to notice it in the pages of the Comptes Renaius, to what appears to me a remarkable discovery in the theory of matrices, or, in other words, of multiple quantity which has lately presented itself to me. It seems to me the more necessary to do so because the nature of the theorem which constitutes the discovery would hardly be suspected from the leading title of the note in the Comptes Rendus in which it is contained, being indeed an after-thought, so that the sting of the paper has to be sought for in its tail.

Hamilton, of immortal memory, has given, in his "Lectures on Quaternions," a solution of a certain quadratic equation in quaternions, those algebraical entities which (building upon a suggestion in Prof. Cayley's ever-memorable paper ${ }^{1}$ on matrices, in the Philosophical Transactions for 1858 or thereabouts) I have, with the general concurrence of all who have given attention to the subject, found means of identifying with binary matrices or algebraical quantities of the second order, and this succeeded in determining the True Place of Quatcrnions in Nature. Now, what Hamilton has done for an equation of the second degree of quantities of the second order, the theorem in question effects in a much more simple and complete manner for a similar sort of equation of any degree and relating to quantities of any order.

The history of the discovery in question constitutes in itself, it seems to me, an interesting chapter in Heuristic. This is how it came about. Hamilton's equation admits of six solutions or roots, which arrange themselves naturally in three pairs, and stand in im. mediate, and what we algebraists call rational, relation to the three roots of a cubic equation, or rather to the six square roots of those three roots. From this it follows immediately that one single condition must be sufficient to reduce the number of distinct roots of the equation in quaternions or binary matrices from six to four, inasmuch as, when two roots of the cubic referred to become equal, two pairs of roots of the original equation must coincide. It naturally therefore became an object of interest to obtain the quantity which, equated to zero, expresses the condition of equality of two roots of this cubic, which of course may be effected by means of a well-known formula for finding the discriminant of a cubic equation; but the quantity so obtained directly from the cubic is of an exceedingly complex form, and leaves the mind entirely unsatisfied as to its true internal composition, just as from a handful of diamond dust it would be impossible to infer the crystalline form which constitutes the true idea, the raison or façon d'être of the glittering gem.

Again and again my mind reverted fruitlessly to the subject until, on September 28 last, pacing the deck of the splendid Dover and Calais boat, the Invicta, under the vivifying and genial rays of a bright and benignant sun, the idea occurred to me that the form to be determined must be subject to satisfy a certain partial differential equation, and without the aid of pen or pencil I succeeded, ere the voyage was half over, in identifying the discriminant of the cubic with that of a biquadratic of the simplest imaginable constitution possible: in technical language, supposing $p x^{2}+q x+r=0$ to be the equation in question, I discovered virtually that the desired discriminant is identical with that of the biquadratic form which is the determinant of the binary matrix (or the tensor squared of the quaternion) $p x^{2}+q x+r$ treated as if $x$ were an ordinary quantity. Starting from this point it was easy to infer all the possible cases of equality which could occur between the six roots; and, more than that, to classify under thirteen classes all the principal cases that could present themselves in the solution of the equation, not merely for the general case when there are six actual and determinate roots, but even for those cases when some of the roots pass off into infinity and become conceptual instead of actual, or else, without passing to infinity, remain actual but contain arbitrary constants.

This more-than-anticipated complete solution of the problem before me was in part suggested by the opening

"This paper constitutes a second birth of Algebra, its avatar in a new and sixtl volume of the American Mathematical Journ.xl. 